\title{
Parent expectations towards participation to extracurricular sport activity of high school students
}

\author{
Yilmaz A. ${ }^{\mathrm{ABCDE}}$ \\ Faculty of Sport Science, Kırlkkale University, Turkey
}

Authors' Contribution: A - Study design; B - Data collection; C - Statistical analysis; D - Manuscript Preparation; E - Funds Collection.

\begin{abstract}
Purpose: $\quad$ Extracurricular activities are the activities that are carried out inside and outside of the school after the class depending upon a plan and program, and that contain the traits designed for the various purposes. This activities are important for adolescents in terms of discovery the skills, interests and strengths, and creating a chance to get to know themselves. Besides, the activities provide to strengthen the relationships with persons in school, and to build up academic success and moral life factors. This study aims to determine the expectations of parents from the extracurricular sportive activities.

Material: In research, interwoven single case study design, one of the qualitative research approaches, was used. Easy accessible sample was benefited for the selection of study group. Parents of 14 students studying in different high schools in the city center of Kırıkkale in 2014-2015 academic years were included in the research. Data were obtained from the semi-structured interview form and applied a content analysis.

Results: $\quad$ As a result of the obtained findings, it was figured out that expectations of parents from the extracurricular sportive activities are generally the contributions of activities on children to spend a quality leisure time. 5 categories were obtained as a result of analysis. These categories are "being a healthy individual", "keeping away from the harmful habits", "socializing", "keeping away from the bad circle of friends", "providing skill development" and "providing being an intellectual individual".

Conclusions: As a result, parental opinions revealed that extracurricular sportive activities are important in terms of children spending a quality leisure time. Parents' expectations from these activities are also in this direction.

Keywords: extracurricular sport activity, interview, parents, qualitative research, expectation.
\end{abstract}

\section{Introduction}

Extracurricular sportive activities are the activities that are performed inside and outside of the school depending on a certain plan and program after the class and that contain features designed for various purposes [1]. In other words, extracurricular activities are defined as an activity that aims to develop children's some special skills and abilities, depending on certain rules, providing inspection through adults and being performed in a programmed way [2]. These activities enable individual to gain many characteristics. These characteristics are: providing physical and psychological security, gaining the sense of belonging to school, gaining positive social norm [3]. Besides, Activities provide the children giving individual an opportunity to develop the skills and providing adaptation to family, school and society [4].

Even though extracurricular activities have some negative results [5], the opinion that these activities have generally a positive effect on the adolescents is quite common [4]. Activities contain the features of adolescents making social circles, identifying their own abilities [5], the development of the sense of self-sufficiency, the increase in their academic successes and many other developmental factors [6]. It is stated that these activities particularly reduce the drug abuse of adolescents [5], and also reduce various behavior tendencies such as absconding from school [7] and committing a crime [8]. In addition, activities are useful for students to gain the

(C) Yılmaz A., 2018

doi:10.15561/18189172.2018.0408 sense of belonging to school [9] and to develop positive attitude for school [6]. Extracurricular activities that provide academic success and serve as an important intercessor [10] can be associated with children's sense of belonging to school [11], their motivation and academic success [12]. School success of adolescents who have the sense of belonging to school shows increase [13]. Studies that handle the relationship between the participation in the extracurricular activities and academic success of adolescents [14] revealed that there was an increase in the weighted educational composite point of the students who participated in extracurricular activities. Particularly, activities give adolescents a chance. They provide gaining and performing social, physical and intellectual skills in a wide area in school [15]. Activities gain to children being a member of society and contribute to public welfare and identify socially a group and belong to it [15]. In addition, to be able to create a social relation with peers and adults that will be able help at the present time and in the future and these activities provide experience and deal with the difficulties [15]. O'Brien \& Rollefson [16] stated that extracurricular activities enable students to learn the importance of team work, individual and group work, physical power and strength, competition, being versatile, culture and society unity.

Since the activities are structured, they have influence on taking adolescents' post-school times under control [17]. Since parents have the chance to control the children's extracurricular times to some extent [18], the fact that thanks to these activities children spend 
the post-school time in a planned and programmed way minimizes the parents' anxieties. Knowledge, skill and ability that students gain from the field of sport prevent adolescents from bad habits by valuing ideally the leisure time. Because these activities are structured and contain inspection, so enable students to participate in the activities in a secure environment. Furthermore, activities give students an opportunity to reveal their own interests in a secure environment until the parents come to home after completing their works [19].

Parents' perspectives for extracurricular sportive activities and their expectations from these activities are the determinative factors in directing the children to these activities. The fact that parents' perspectives for sportive activities are positive can show that they have the awareness about the expectation from the activities. Families can make a positive inference from children's successes obtained from these activities. Accordingly, they can support their children to participate in these activities. There is a positive relationship between family support and the pleasure that children get from the sport [20]. In society, child's success and failure are attributed completely to families. When the children get success in sports, people believe that it is the family factor that stands behind this success. For instance, when Tiger Woods, a famous golf player, started showing success in tournaments, everyone described Earl Woods, Tiger's father, as a good and smart parent and considered him as fundamental support behind Tiger's success. The same situation is seen in the example of Richard William, father of Serena and Venus Williams [21]. Studies that examine the attitudes and opinions of parents for extracurricular sportive activities $[22,23]$ were encountered in literature, there were limited studies that handle their expectations from these activities $[24,25]$. This conducted study is important in terms of revealing the parents' expectations and it is expected that this study will provide a different perspective for researchers and implementers about extracurricular sportive activities being more qualified by evaluating the obtained results.

\section{Materials and methods}

\section{Research Model}

In research carried out to determine the parents' expectations from the extracurricular sportive activities; interwoven single case study design, one of the qualitative research approaches [26] was benefited. Case study designs are expressed as an analysis and definition of an example, fact or social unit in a holistic way [27].

Participants:

In the selection of study group was used easy accessible case sampling, one of the purposeful sampling methods that contain sample units which serve for the research [28]. This sampling provides energy and pecuniary resource by reaching the sample in a fast and easy way [29] so that detailed information on research can be collected and data quality can be high [30]. Parents of 14 students studying in different high schools in the city center of Kirıkkale in 2014-2015 academic years were included in the research.

\section{Data Collection}

Semi-structured interview form that was prepared for the interview used in the qualitative chapter of research. This form was applied on 14 parents between the dates of 05.09.2015 and 11.09.2015 in the city center of Kırikkale in a place and time period that participants saw fit.

Semi-Structured Interview Form:_Interview method was used in present study to obtain profoundly information on the subject. Interview is an instrument that provides to reveal what people think and why; what their feelings, attitudes and emotions are and which factors lead their behaviors [31]. In interview, questions are addressed to participants for a purpose and answers are received in a mutual communication process [33]. Kvale [34] tried to explain this process with a miner metaphor. Interview process can be likened to an excavation that miner carries out deeply to seek a mine. In just the same way as a miner excavates to find a valuable mine. Research tries to learn and reveal the individuals' way of thinking, perceptions, thoughts, emotions and remarks through a systematic question within the scope of results intended to be revealed [35]. The use of interview technique changes according to the aim of research object. In this study, semi-structured interview form was used to determine the parents' opinions on extracurricular sportive activities. In the semi-structured interview form that Bogdan \& Biklen [32] suggest and that gives participants a chance to express freely their thoughts about a certain subject, researcher gets profoundly information through questioning that provides to obtain true data. In this interview, preprepared questions guide researcher during the interview. The reason why this interview technique was selected is that it has the flexibility of addressing new questions to participants pending the interview $[36,37]$.

$\checkmark$ Specific questions for each subject,

$\checkmark$ Fact that will be handled for each subject and specific questions for each fact,

$\checkmark$ Specific instructions for each subject, fact and question [38].

Before preparing the semi-structured interview form, studies about the subject [39] and studies in which the interview technique used in qualitative research was used were examined. The questions and questions that serve for the aim of research were prepared. These questions were presented to evaluations of 5 (five) experts. This experts are 3 from the field of physical education in terms of content validity, 1 from the field of Turkish education in terms of legibility and understandability and 1 from the field of assessment and evaluation. Questions in the interview form prepared in the direction of experts' suggestions and criticisms were tested by interviewing with two parents that have similar characteristics with participants. Evaluating the reactions of participants to questions after this pilot practice, corrections were made in the direction of feedbacks obtained from them and final form was given. It was determined as a result of pilot practice that duration of interviews changed between 5-16 minutes. Questions included in the interview form were prepared based on literature; it was aimed to 
examine deeply the subject and to prepare questions that aim to examine diffusively the reasons lying behind the behaviors. Parents were asked their opinions that contain their perspectives for extracurricular sportive activities and their expectations from these activities. The interview form consists of two chapters. In the first chapter, there are questions about interview date, the time of interview, nickname in the interview, person's name of interviewer and the chapter in which the aim of interview is introduced to participant. In the second chapter, questions about research were presented. Questions included in the interview form were given below:

$\checkmark \quad$ First of all, what is your general opinion about the extracurricular sportive activities?

$\checkmark$ What are your expectations from the extracurricular sportive activities?

\section{Data Analysis}

Before starting to analyze, interview records obtained by researcher from participants were transferred into text. In this process, listening were carried out repeatedly to prevent data loss. In case confusion can occur during and after the analyses, participant interview forms were enumerated from K1 to K14. Every participant was given nicknames. The aim here is to provide evidence for validity by supporting the themes revealed in the findings chapter with participant opinions. In the data analysis, content analysis that requires interpreting the similar data by gathering them as part of concepts and themes and arranging them in a way that readers can understand [40] was used. In the process of analysis, the below steps were followed;

$\checkmark \quad$ The obtained data were read by the researcher by reviewing it over and over, and code list was created by writing codes. Because in the qualitative analysis, codification is the first and fundamental process for the analysis to find out the data contents [41]. By evaluating the data obtained as a result of interview, codifications were conducted as part of research problem. In the analysis; words, sentences and paragraphs used for the determination of the participants' statements were coded by conceptualizing them [42].

$\checkmark \quad$ Afterwards, codes were categorized by gathering them according to their common traits. The subcategories under these categories and the codes representing these categories were interpreted by getting explained in relevant to each other, and the results were received [43].

$\checkmark$ Literature and relevant studies were benefited for the interpretation of the obtained findings. In addition, the obtained data were tabulated and findings were interpreted by including the participant opinions. Accordingly, it was tried to provide the validity of the obtained data.

Validity and Reliability

Validity can be provided with an impartial observation as far as possible and a natural state of the research subject. Process steps followed concerning the validity and reliability were indicated in Table 1.

Data were analyzed separately by another expert apart from the researcher to determine whether or not the conceptual categories obtained. As a result of data analysis aimed at research reliability represent the obtained themes and the obtained codes. The categories that codes represent were compared. Both researchers discussed the dissenting points and reached agreement. The formula of Miles \& Huberman [50] [Agreement/ (Agreement + Dissent) x 100] was calculated to provide the data reliability. Agreement among experts was calculated as $96 \%$ for the reliability of study results.

Research Environment

Appointments were gotten from the participants to receive their opinions on the researcher and interview time and place were determined. The quality of place where the interview is carried out is significant in terms of the quality of information that researcher will obtain. Therefore, it was paid attention to prefer places where the factors such as sounds, noises etc. that can disable the communication between the researcher and participant can be minimized.

Table 1. Validity and reliability criteria towards qualitative research

\begin{tabular}{|c|c|c|}
\hline \multirow[b]{2}{*}{ Validity } & Internal Validity & $\begin{array}{l}\text { Receiving expert opinions } \\
\text { Participant confirmation } \\
\text { Spending a long time with participants } \\
\text { Direct quotation }\end{array}$ \\
\hline & External Validity & $\begin{array}{l}\text { Explanation of data collection tool and process } \\
\text { Explanation of data analysis process } \\
\text { Explanation of characteristics of study group } \\
\text { Explanation of role of researcher } \\
\text { Explanation of reason of selection of the used method } \\
\text { Explanation of validity and reliability precautions }\end{array}$ \\
\hline \multirow{2}{*}{ Reliability } & Internal Validity & $\begin{array}{l}\text { Preventing data loss by using recorder } \\
\text { Presenting directly the findings }\end{array}$ \\
\hline & External Validity & $\begin{array}{l}\text { Discussing the data in a proper way } \\
\text { Controlling the consistency between the data }\end{array}$ \\
\hline
\end{tabular}

[*44-49]* validity and reliability criteria related to research. 
Moreover, requests of the participants who are the target resources were considered for the selection of place so that they can feel comforted and express themselves well. The recordings of the participants' opinions on the interview were given in Table 2.

In Table 2; information on the date, time and place of the interview carried out with participants were given. Interviews with participants were done after getting an appointment. Interviews were carried out with participants one to one between the dates of 05.09.2015 and 11.09.2015. Importance was given to prefer places which participants considered as appropriate.

\section{Results}

Findings about parents' expectations from the extracurricular sportive activities were indicated in Figures. It can be said that each of these expectations has the aim of children spending the post-school time in a quality way. It appears that the frequencies of parents' expectations from extracurricular sportive activities are respectively "being a healthy individual $(n=11)$ ", "Keeping away from the harmful habits $(n=8)$ ", "socializing $(n=7)$ " and "keeping away from the bad circle of friends $(n=5)$ ". Two categories with the lowest frequency are "providing skill development $(n=3)$ ". Opinions towards parents' expectation with the highest frequency were given below.
It was seen that parents expected from these activities to make their children physically and psychologically good and to provide children to have a high sense of selfconfidence.

The category of "being a healthy individual" has the highest frequency in terms of participants' expectations from extracurricular sportive activities. This category contains the sub-categories of "feeling psychologically relieved" and "having a good physical development". Parents generally stated the necessity of these activities to be functional in terms of children being psychologically healthy individuals. Ayse, one of the participants, specified that her expectation from these activities is her child feeling psychologically relieved:

"... I think that sport will be effective in terms of child resting and gathering thoughts back with other things by taking up sports. "Kubra's expectation from these activities is similar, as well: "It is a thing getting rid of thoughts in her mind through sport... Perhaps she can be physically tired but she can mentally relax, I think she will have a different mood".

It was determined that participants have expectations from these activities that contain opinions on children regenerating mentally, being psychologically steady like having a good mood. The other sub-category of the category of being a healthy individual is "having a good

Table 2. Information on time and place of interview

\begin{tabular}{lllll}
\hline Participant & *Nickname & $\begin{array}{l}\text { Date of } \\
\text { Interview }\end{array}$ & $\begin{array}{l}\text { Time of } \\
\text { Interview }\end{array}$ & Place of Interview \\
\hline K1 & Fatih & 05.09 .2015 & $12.35-12.45$ & Kırıkkale Police Headquarters \\
K2 & Ayse & 05.09 .2015 & $14.05-14.22$ & Public Health Directorate \\
K3 & Yasemin & 07.09 .2015 & $11.35-11.46$ & Community Health Center \\
K4 & Songul & 07.09 .2015 & $14.59-15.05$ & Public Health Directorate \\
K5 & Neriman & 07.09 .2015 & $15.30-15.35$ & Public Health Directorate \\
K6 & Kubra & 08.09 .2015 & $12.05-12.16$ & Public Health Directorate \\
K7 & Mehmet & 09.09 .2015 & $15.40-15.49$ & Community Health Center \\
K8 & Mustafa & 09.09 .2015 & $17.41-17.50$ & Kırıkkale /City Center \\
K9 & Izzet & 10.09 .2015 & $14.18-14.25$ & Kırıkkale /City Center \\
K10 & Sukran & 10.09 .2015 & $16.43-16.49$ & Kırıkkale/Kaletepe (Home Visit) \\
K11 & Meral & 10.09 .2015 & $18.17-18.26$ & Kırıkkale/City Center (Home Visit) \\
K12 & Canan & 11.09 .2015 & $10.07-10.15$ & Kırıkkale/City Center (Home Visit) \\
K13 & Emine & 11.09 .2015 & $15.16-15.28$ & Kırıkkale/City Center (Shop) \\
K14 & Yasin & 11.09 .2015 & $19.27-19.32$ & Kırıkkale/City Center (Grocery Store) \\
\hline
\end{tabular}

* Names mentioned above are the nicknames that represent the participants included in the study.

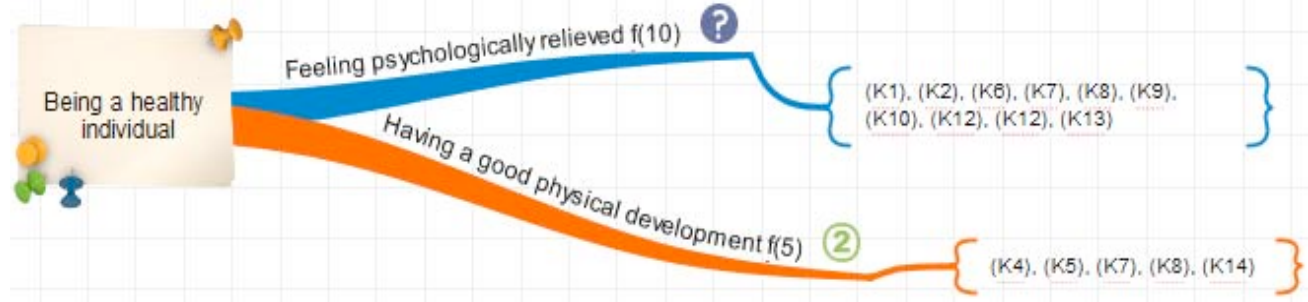

Figure 1. The category of being a healthy individual 
physical development". In this sub-category, it was stated that participants have expectations such as providing children's weight control, their children growing tall, muscle development, having a good posture through extracurricular sportive activities. It appeared that some participants direct their children to a sport branch by carrying out researches on which sportive activity could contribute more to physical development of children. Here is the opinion of Mehmet about this subject:

"My child plays football. I wanted to choose different fields. I wanted him to build muscles for physical development, for health. I encouraged him... For example, I tell him to go to basketball to grow tall. Tell him to go swimming to exercise his all muscles. I try to direct him by expressing these". Mustafa's opinion on extracurricular sportive activities supporting the physical development of children is so: "I want him to have physically an adequate structure. Reasons like getting tall or not to gain weight". It was figured out that participants have expectations from these activities in terms of their children's physical and psychological developments.

The category of "keeping away from harmful habits" has the second highest frequency in terms of participants' expectations from extracurricular sportive activities. This category shows that there are participants' expectations in terms of preventing children to spend a long time with social media, television and smartphone. Stating particularly that adolescents spend a long time with social media or smartphone, participants specified the importance of extracurricular sportive activities in terms of spending the post-school time in a more qualified way. Ayse, one of the participants, stated that her child is always at the computer or phone when he is at home and she is troubled with this situation.

"We take our son's phone from him when he is at home. He is occupied either with computer or phone.
He needs to study for university exam because he is in senior class. No matter how much we struggled, we could not prevent him from some things. However, we tried to keep him away from harmful habits through restrictions like taking his phone. At this point, I support his participation in sportive activities".

"He is now at the computer. He is always at the computer after coming from the school. So he has not a quality and qualified life. I wish he can spend the time with sport (Songul)".

"After the classes, she spends time at the computer and smartphone at home. That is why I cannot get in contact with her (Neriman)".

Other participants have similar problems and their opinions for the increase in their belief in children to be able to spend more quality time thanks to these activities are so:

“...in post-school times, he sometimes goes out on the street. Mostly he sits at home. He spends lots of time with computer and smartphone. We get angry him but he does not listen us. I want him to participate in these activities but he does not want (Meral)".

"...we want him to exercise at the least since he is at the computer so much time. The fact that he cannot go out so much and accordingly spends so much time at the computer worries us and obesity that is the illness of our age is on the agenda. We want him to exercise, to make friends and to identify his own skills (Canan)". Another one of parents' expectations from extracurricular sportive activities is socializing $(\mathrm{n}=7)$.

In the category of socializing, there are three subcategory which are having new friends $f(3)$, having new environment $\mathrm{f}(2)$ and having different circles.

"I myself took my child to swim course and picked up him from course so that he can make new friendships, discover new environments (Fatih)'”.

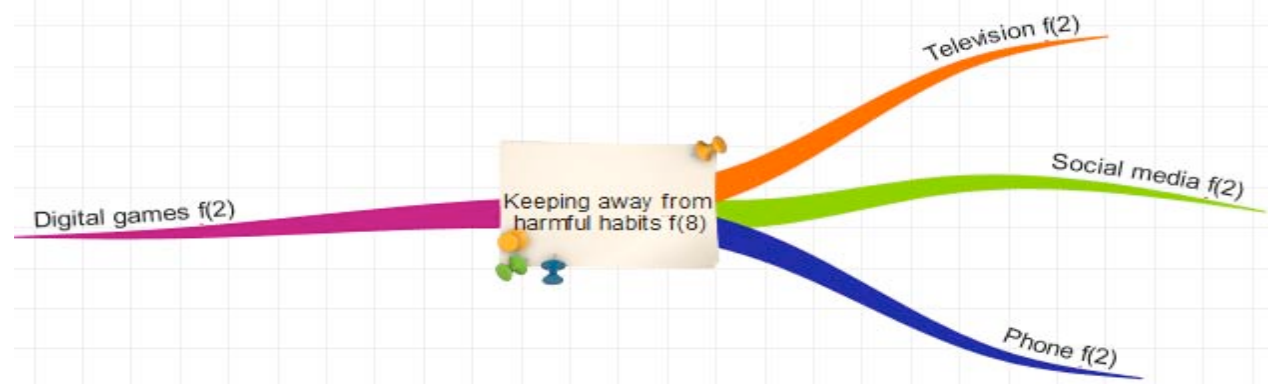

Figure 2. The category of keeping away from harmful habits

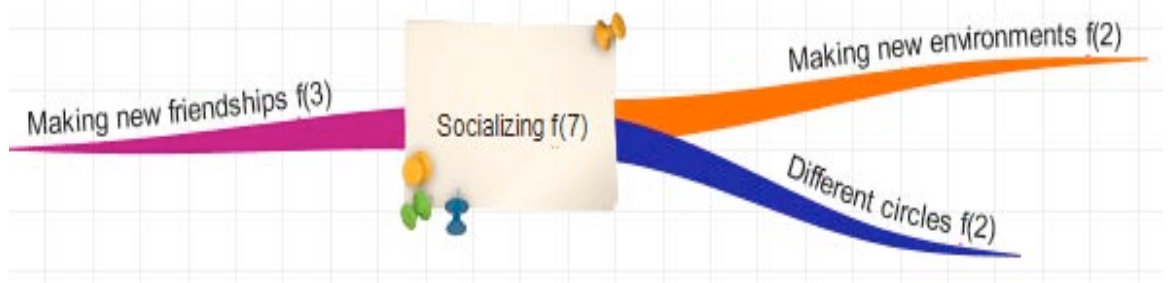

Figure 3. The category of socializing 
“... Does not exercise, because he is at the computer now. Always computer after the school. Therefore, he does not have a qualified and quality life. If there was sport, he could have some certain times in his life. He could both have a conversation with his friends and walk around. Also he could play sports (Songul)".

"...He spends post-school time at the computer or being occupied with smartphone at home. Since he gets bored and especially he is not active in any sportive activities in this period called the puberty, he fights with his siblings. We cannot get in contact with him, cannot talk with him. This is because of computer, but not that much (Neriman)." One of the another category of expectation of parents is keeping away from bad circle of friends $\mathrm{f}(5)$.

As shown in Figure 4, this category consists of two sub-categories that are preventing smoke and drug and alcohol use. The opinions related to category are given below.

"Because of the period child is in, he is always after something. For a moment in past, he started smoking just because his friends smoked. But we made him give up smoking. If he participates in these activities, perhaps he will contact with others and his introversion will be gone. I will know where he is. At the moment, I worry about where he is. For example, if you smoke here, I will also want to smoke. These activities keep the child away from the bad circle of friends (Meral)".

“...In my opinion, activities keep child away from bad habits. School, sportive activity and course take already child's time. So child has not so much time to make bad friends. He goes to sport, he goes to sport in school, then he studies; therefore, he cannot find time to make bad circle of friends and habits... being under teachers' inspection, physical education teachers' inspection or trainers' inspection keeps already child away from these bad habits and circles (Canan)".

"...Because participating in these activities keep my children away from bad habits and behaviors. I mean that when they exercise these activities out there, I think they are prevented from bad habits and making bad friends since they exercise under a better teacher or trainer and they are not left unconfined in a way. They have a regular life-style, at least I think so (Kubra)".

Participants' expectations are their children to prevent from bad habits such as smartphone addiction or computer which has become the illness of our age for adolescents. Most of parents do not have any idea how to put this habit away. At this point, it can be said that parents have the expectations that spending post-school time by participating in these activities can enable children to spend time usefully. Other subjects parents worry about are drug abuse, smoke and alcohol which reveal because of bad circle of friends of children. Particularly, nowadays providing the addictive drug is easy and adolescents spend more time with friends than family; therefore, it gets easy to gain these bad habits. Participation in the extracurricular sportive activities makes it easier for parents to know the children's circle of friends and the place they are in and to control their children. The last category related to expectation of parents about extracurricular sport activity is providing skill development $\mathrm{f}(2)$.

As shown in Figure 5, this category consists of two sub-categories that are exploring children ability and being able to do the movements peculiar to sport branch. The opinions related to category are given below.

"I want from my child to identify her own skills and to feel the sense that I can do something (Canan)".

"Since I could not swim, I was always at the coast. I directed my child to the swimming team of school so that he can develop his swimming skill (Fatih)".

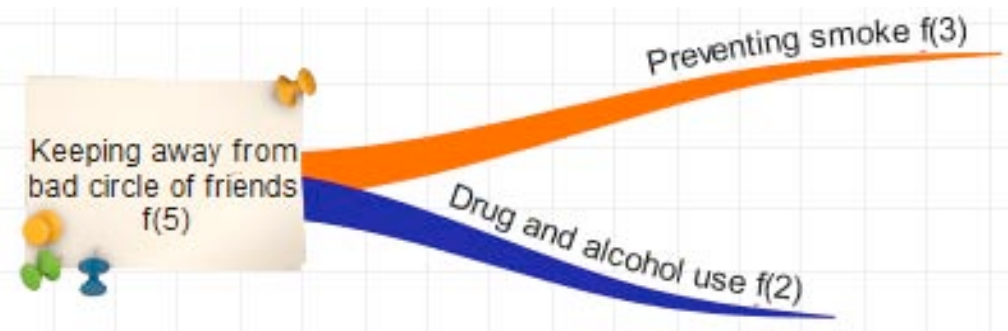

Figure 4. The category of keeping away from bad circle of friends

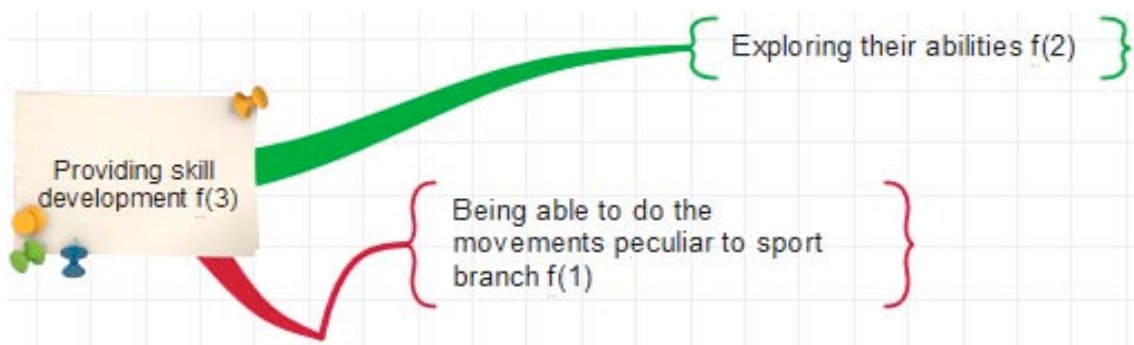

Figure 5. The category of providing skill development 


\section{Discussion}

In this research, documents were examined which were obtained as a result of interviews carried out to identify the expectations of parents from extracurricular sportive activities. Parents expressed their expectations as "being a healthy individual", "keeping away from the harmful habits", "socializing", "keeping away from the bad circle of friends", "providing skill development" and "providing being an intellectual individual". The category of being a healthy individual contains the contribution psychologically on children's development. In the study of [51], it was revealed that these activities contribute psychologically to children's development. Similar result was obtained in the study of [15] entitled extracurricular activities and adolescent development. It was concluded that individuals' skills and social relationships, school success, educational and professional level, welfare level, health and positive social behaviors developed with the participation in activities. Extracurricular sportive activities support the physical development of adolescents. Parents asserted two concepts under health category which are psychological and physical development concepts.

Parents drew attention to importance of extracurricular sportive activities in terms of children displaying physically healthy development. It was determined that parents have expectations that sport enables their children to control their weight and provides adolescence's effect on human physiology to be balanced, children can get tall especially with sportive branches. It was seen that particularly some parents have a high awareness level towards the sport's effects on children. They direct their children to a sport branch by carrying out researches on which sportive activity could contribute more to physical development of children. Mahoney, Larson \& Eccles [52] emphasized that these activities contribute to physical development of children and adolescents. O'Brien \& Rollefson [16] revealed that extracurricular activities give students an opportunity to learn acquisitions such as rivalry, physical power and strength.

Remarking that with the development of technology, addiction level of children to smartphone and computer has increased, parents stated that children could be more active thanks to the participation in these activities. For instance, Bartko \& Eccles [53] revealed that unstructured activities, which are defined as an inactive life style such as spending time at computer or watching television, could generally cause problems for children and adolescents. In the study of Gurkan \& Ball1 [54] 'Parents' expectations and opinions about children's participation in leisure time activities and sports", it was figured out that children preferred mostly passive activities such as watching television, listening music, spending time at computer and internet. In the same study, parents stated that they wanted children to participate in active sportive activities instead of passive activities. In another study on high school students in US; Larson et al. [55] revealed that students spend limited time with parents and they are occupied more in passive activities such as watching television, surfing on internet, playing video games during the school time.

Parents remarked that children can stay away from bad circle of friends and harmful habits thanks to these activities. There are studies that support these findings $[6,24]$. In the study of Franklin [19], it was determined that since these activities are structured in a planned and programmed way and parents know what their children do and how they spend the time after school, they have low anxiety levels. Particularly, working parents have limited chance to control their children's extracurricular time [18], they specified that these activities enable their children to spend the post-school time in a planned and programmed way.

Structured extracurricular activities create conditions for children to acquire different social skills which couldn't be developed with normal studies in school [56]. It was figured out that parents' expectations from these activities are in this direction. Parents emphasized that activities have a great contribution on children to make new friendships, to gain leadership skills and to collaborate with other individuals. There are studies which reveal that structured activities that affect directly the development of adolescents play a role in changing their nature of social development [57]. Study of Darling [58] indicated that these activities enable adolescents to socialize with their peers, to set a target and achieve it, to compete fairly and to resolve the problems peacefully. Study of Darling et al. [4] indicated that activities provide adolescents to perform the common interests together and accordingly enable them to create new relationships with their peers and to gain social capital.

Another expectation of parents from extracurricular sportive activities is to contribute to skill developments of their children. Study of Akgul et al. [59] supports present study. In study, it was concluded that thanks to activities children and adolescents can spend the leisure time in a good way, they use their energies positively and they can prevent themselves from bad habits and develop their knowledge, skills and abilities by getting rid of stress. That is because lessons that are lectured in school might not contain everything for children's education. These can be provided by extracurricular activities in the direction of the aim of education. Through extracurricular activities, insufficiency of typical education programs is fulfilled; students' physical and spiritual necessities are taught by experiencing and conducting it on vital problems; skill developments of students are provided [60].

\section{Conclusion}

Considered the findings related to subject, it appeared that the biggest anxieties of parents about children are that children have bad circle of friends and gain bad and harmful habits. It was revealed that they have expectations from extracurricular sportive activities in terms of dealing with these harmful and bad habits. The facts that these activities are performed under adult (trainer, family etc.) and structured in a planned and programmed way prompt parents to direct their children to these activities for post-school time. In this direction, 
expectations from these activities can be summarized so: supporting healthy developments of children, keeping away from harmful habits, giving opportunity to socialize, keeping away from bad circle of friends, supporting skill development and giving a chance to be an intellectual individual. Considered these results, it can be said that effect of extracurricular sportive activities on adolescent development is incontrovertibly significant. Therefore, it should be given importance to perform extracurricular sportive activities, giving a chance for parents to follow closely these activities.

\section{Conflict of interest.}

The authors state that there is no conflict of interest.

\section{References}

1. Balyer A, Gündüz Y. Effects of Structured Extracurricular Facilities of Students' Academic and Social Development. Procedia-Social and Behaviour Science, 2012; 46: 48034807.

2. Ivaniushina VA, Aleksandrov DA. Socialization through Informal Education: The Extracurricular Activities of Russian School Children. Russian Education \& Society, 2015; 57(4): 189-213.

3. Toomey RB, McGuire JK, Russell ST. Heteronormativity, School Climates, and Perceived Safety for Gender Nonconforming Peers. Journal of Adolescence, 2012; 35(1): 187-196.

4. Darling N, Caldwell LL. Smith, R. Participation in School Based Extracurricular Activities and Adolescent Adjustment. Journal of Leisure Research, 2005; 37(1): 51-56.

5. Eccles JS, Barber BL. Student Council, Volunteering, Basketball, or Marching Band: What Kind of Extracurricular Involvement Matters? Journal of Adolescent Research, 1999; 14(1): 10-43.

6. Fredricks JS, Eccles JA. Participation in Extracurricular Activities in The Middle School Years: Are There Developmental Benefits for African/American and European American Youth? Journal of Youth Adolecence, 2008; 37(9): 1029-1043. doi:10.1007/s10964-008-9309-4

7. Mahoney JL, Stattin H. Leisure Activities and Adolescent Antisocial Behavior. The Role of Structure and Social Context. Journal of Adolescence, 2000; 23: 113-127.

8. Harrison PA, Narayan G. Diffirences in Behavior, Phychological Factors, and Environmental Factors Assosiated with Participation in School Sports and Other Activities in Adolescence. Journal of School Health, 2003; 73(3): 113-120. doi: 10.1111/j.1746-1561.2003.tb03585.x

9. Mahoney J, Cairns R. Do Extracurricular Activities Protect against Eaerly School Dropout? Developmental Phycology, 1997; 33(2): 241-253.

10.Knifsend CA, Graham S. Too Much of a Good Thing? How Breadth of Extracurricular Participation Relates to SchoolRelated Affect and Academic Outcomes During Adolescence. Journal of Youth and Adolescence, 2012; 41(3):379-389. doi:10.1007/s10964-011-9737-4

11.Anderman EM. School Effects on Psychological Outcomes During Adolescence. Journal of Educational Psychology, 2002; 94(4): 795-809. doi:10.1037/0022-0663.94.4.795

12.Barber BL, Eccles JS, Stone MR. Whatever Happened to The Jock, The Brain, and The Princess? Young Adult Pathways Linked to Adolescent Activity Involvement and Social İdentity. Journal of Adolescent Research, 2001; 16(5): 429455.

13.Marsh H. Extracurricular Activities: Beneficial Extension of The Traditional Curriculum or Subversion of Academic Goals? Journal of Educational Psychology, 1992; 84(4): 553-562. doi:10.1037/0022-0663.84.4.553

14.Hansen DM, Larson RW, Dworkin JB. What Adolescents Learn in Organized Youth Activities: A Survey of SelfReported Developmental Experiences. Journal of Research on Adolescence, 2003; 13(1):25-55. doi:10.1111/15327795.1301006

15.Eccles JS, Barber BL, Stone M, Hunt J. Extracurricular Activities and Adolescent Development. Journal of Social Issues, 2003; 59(4): 865-889. doi:10.1046/j.00224537.2003.00095.x

16.O'Brien E, Rollefson M. Extracurricular Participation and Student Engagement. National Center for Education Statistics Policy Issues, 1995; 95(741): 1-4.

17.Floyd MF, Bocarro JN, Thompson T. Research on Race and Ethnicity in Leisure Studies: A Review of Five Major Journals. Journal of Leisure Research, 2008; 40(1):1-22.

18.Shannon CS. Parents' Messages about The Role of Extracurricular and Unstructured Leisure Activities: Adolescents' Perceptions. Journal of Leisure Research, 2006; 38(3):398-420.

19.Franklin J. It Takes a Community: Keeping Extracurricular Activities Available for At-Risk Students. [cited 2004 Dec 10]. Available from: http://www.ascd.org/publications/ newsletters/education-update

20.Anderson JC, Funk JB, Elliott R, Smith PH. Parental Support an Pressure and Children's Extracurricular Activities: Relationships with amount of Involvement and Affective Experience of Participation. Journal of Applie Developmental Psychology, 2003;24(2):241-257. doi:10.1016/S01933973(03)00046-7

21.Coakley J. Sports in Society (Issues and Controversies). (Eighth Edition). Singapore. 2003.

22.Larson RW, Hansen DM, Moneta G. Differing Profiles of Development Experiences Across Types of Organized Youth Activities. Developmental Psychology, 2006; 42(5): 849863. doi:10.1037/0012-1649.42.5.849

23.Kremer-Sadlık T, Izquierdo C, Fatiante M. Making Meaning of Everyday Practices: Parents' attitudes toward Children's Extracurricular Activities in the United States and in Italy. Anthropology ve Education Quarterly, 2010; 41(1):35-54.

24.Yılmaz A. Lise Öğrencilerinin Ders Dışı Sportif Etkinliklere Katılımına Yönelik Ebeveyn Tutum ve Görüşleri [Parents' Attitude and Opinions Towards Participation to Extracurricular Sport Activity of High School Students]. Gazi Üniversitesi Eğitim Bilimleri Enstitüsü; 2016. (in Turkish)

25.Y1lmaz A, Güven, Ö. Parents Attitude Scales towards Extracurricular Sport Activities. Niğde University Journal of Physical Education and Aport Sciences, 2015; 9(2):244-258. (in Turkish)

26.Merriam SB, Tisdell EJ. Qualitative Research: A Guide to Design and Implementation. John Wiley \& Sons; 2015.

27.Yin RK. Case Study Research: Design and Methods. California: Sage; 2014.

28.Creswell JW, Creswell JD. Research Design: Qualitative, Quantitative, and Mixed Methods Approaches. Sage publications; 2017.

29.Baș T, Akturan U. Nitel Araştırma Yöntemleri: Nvivo ile Nitel Veri Analizi, Örnekleme, Analiz, Yorum [Qualitative Research Methods: Qualitative Data Analysis with Nvivo, Sampling, Analysis, Interpretation]. Ankara: Seçkin Publication; 2013. 
(in Turkish)

30.Patton MQ. Qualitative Evaluatiton and Research Methods. 2nd ed. Thousand Oaks, CA: Sage Publications; 2015.

31.Ekiz D. Bilimsel Araştırma Yöntemleri: Yaklaşım, Yöntem ve Teknikler. [Scientific Research Methods: Approach, Method and Techniques]. Ankara: An1; 2009. (in Turkish)

32.Bogdan RC, Biklen SK. Qualitative Research for Education: An Introduction to Theories and Methods (4th ed.), New York: Pearson Education; 2003.

33. Gay LR, Mills GE, Airasan P. Educational Research: Competencises for Analysis and Applications. New Jersey: Pearson Ecucation, Inc.; 2006.

34.Kvale S. Interviews an Introduction to Qualitative Research Interviewing. Thousand Oaks, CA: Sage; 1996.

35.Türnüklü AA. Qualitative Participation Technique to be Effectively Used in Educational Research: Interview. Educational Administration: Theory and Practice, 2000; 6(4);543-559.

36.Çepni S. Araştırma ve Proje Çalışmalarına Giriş [ Introduction to Research and Project Studies]. Trabzon: Pegem A; 2012. (in Turkish)

37.Ekiz D. Eğitim Araştırmalarında Yöntem ve Metotlarına Giriş: Nitel, Nicel ve Eleştirel Kuram Metodolojisi [Introduction to Methods and Methods in Educational Research: Qualitative, Quantitative and Critical Theory Methodology]. Ankara: An1; 2003. (in Turkish)

38. Cohen L, Manion L, Morrison K. Research Methods in Education (The fifth Edition) New York: Routledge; 2007.

39.Masia JR, Plaza DM, Gonzalez VH, Deltell CJ, Roriguez JC. Parental Attitudes towards Extracurricular Physical and Sports Activity in School-Age Children. Journal of Human Sport and Exercise, 2013;3(8):8-876. doi:10.4100/ jhse.2013.83.

40.Yıldırım A, Şimşek H. Sosyal Bilimlerde Nitel Araştırma Yöntemleri [Qualitative Research Methods in the Social Sciences]. Ankara: Seçkin; 2011. (in Turkish)

41.Punch KF. Introduction to Social Research: Quantitative and Qualitative Approaches. SAGE; 2005.

42.Brott PE, Myers JE. Development of Professional School Counselor Identity A Grounded Theory. In: S. B. Merriam (Ed), Qualitative Research in Practice Examples for Discussion and Analysis. San Francisco: Jossey-Bass A Wiley; 2002. P. 145-160.

43. Maykut P, Morehouse R. Beginning Qualitative Research: A Philosophic and Practical Guide. London: The Falmer; 1994.

44.Kirk J, Miller ML. Reliability and Validity in Qualitative Research. Sage; 1986.

45.Merriam S. What Can You Tell From an N Ofl?: Issues of Validity and Reliability in Qualitative Research. PAACE Journal of Lifelong Learning, 1995; 4: 50-60.

46.Ritchie J, Lewis J, Nicholls CM, Ormston R. (Eds.). Qualitative Research Practice: A Guide for Social Science Students and Researchers. Sage; 2013.
47.Silverman D. (Ed.). Qualitative Research. Sage; 2016.

48.Twycross A, Shields L. Validity and Reliability-What's It All About? Part3 Issues Relating to Qualitative Studies. Pediatric Nursing, 2005; 17: 36-42.

49.Y1ldırım A. Qualitative Research Methods: Basic Characterisics and Implications for Educational Research. Education and Science, 1997; 2(17): 7-17.(in Turkish)

50.Miles MB, Huberman AM. Qualitative Date Analysis. (second edition). United Kingdom: Sage pub.; 1994.

51.Fredricks JA, Alfeld C, Eccles JS. Developing and Fostering Passion in Academic and Nonacademic Domains. Gifted Child Quarterly, 2010; 54(1):18-30. doi:10.1177/0016986209352683

52.Mahoney JL, Larson RW, Eccles JS. (Eds.) Organized Activities as Contexts of Development: Extracurricular Activities, After School and Community Programs. Psychology Press; 2005.

53.Bartko WT, Eccles JS. Adolescent Participation Instructured and Unstructured Activities: A Person-Oriented Analysis. Journal of Youth and Adolescence, 2003; 32(4):233-241. doi:10.1023/A:1023056425648

54.Gürkan E, Ballı ÖM.The Parents' Opinion and Expectations about Their Children's Leisure Time Activities and Sport Participation. Celal Bayer University Journal of Physical Education and Sport Science, 2014; 6(1):36-46. (in Turkish) 55.Larson RW, Richards MH, Sims B, Dworkin J. How Urban African American Young Adolescents Spend Their Time: Time Budgets for Locations, Activities, and Companionship. American Journal of Community Psychology, 2001; 29(4):565-597. doi:10.1023/A:1010422017731

56.Feldman AF, Matjasko JL. The Role of School-Based Extracurricular Activities in Adolescent Development: A Comprehensive Review and Future Directions. Review of Educational Research, 2005; 75(2):159-210.

57.Marsh H, Kleitman S. Extracurricular School Activities: The Good, The Bad, and The Nonlinear. Harvard Educational Review, 2002; 72(4): 464-515. doi:10.17763/ haer.72.4.051388703v7v7736

58.Darling N. Participation in Extracurricular Activities and Adolescent Adjustment: Cross-Sectional and Longitudinal Findings. Journal of Youth and Adolescence, 2005; 34(5):493-505.

59.Akgül S, Göral M, Demirel M, Üstün ÜD. An Investigation of Primary School Students Participation and not Participation Reasons of Extracurricular Sport Activities. Dumlupınar University Journal of Social Science, 2012; 1(32): 13-22. (in Turkish)

60.Karslı S. Illköğretim Okullarında Sosyal Kulüp Çalışmalarının Ögrencilerin Yöneticilik Niteliklerinin Gelişmesine Katkısı: Beypazarl Illçesinde Bir Araştırma [Contribution to the Development of the Managerial Qualities of Students of Social Club Studies in Elementary Schools: A Study in the Beypazarı District]. Gazi Üniversitesi Eğitim Bilimleri Enstitüsü: 200;. (in Turkish) 


\section{Information about the author:}

Yılmaz Aynur; Research Asssistant PhD.; http://orcid.org/0000-0001-7562-9469; yilmazaynr@hotmail.com; Faculty of Sport Science, Kırıkkale University; Yahsihan, Kırıkkale, 71450, Turkey.

Cite this article as: Y1lmaz A. Parent expectations towards participation to extracurricular sport activity of high school students. Pedagogics, psychology, medical-biological problems of physical training and sports, 2018;22(4):216-225. doi:10.15561/18189172.2018.0408

The electronic version of this article is the complete one and can be found online at: http://www.sportpedagogy.org.ua/index.php/PPS/issue/archive

This is an Open Access article distributed under the terms of the Creative Commons Attribution License, which permits unrestricted use, distribution, and reproduction in any medium, provided the original work is properly cited (http://creativecommons.org/licenses/by/4.0/deed.en)

Received: 25.06.2018

Accepted: 16.07.2018; Published: 30.08.2018 